\title{
The impact of highly active antiretroviral therapy on the survival of vertically HIV-infected children and adolescents in Belo Horizonte, Brazil
}

\author{
Claudete Aparecida Araújo Cardoso, Jorge A Pinto $/{ }^{+}$, Talitah Michel Sanchez Candiani, \\ Inácio Roberto de Carvalho, Renato Moreira Linhares, Eugênio Marcos Andrade Goulart \\ Grupo de Pesquisas em HIV/AIDS Materno-Infantil, Faculdade de Medicina, Universidade Federal de Minas Gerais, \\ Av. Alfredo Balena 190/161, 30130-100 Belo Horizonte, MG, Brasil
}

The use of highly active antiretroviral therapy (HAART) for human immunodeficiency virus (HIV)-infected patients has reduced the number of acquired immune deficiency syndrome-related deaths worldwide. This study assessed the impact of HAART on the survival and death rates of vertically HIV-infected children and adolescents in Belo Horizonte, Brazil. Data were obtained from a historic cohort of vertically HIV-infected children and adolescents aged zero-19 years old who were admitted from March 1989-December 2004 and were followed until June 2006. Patients who used HAART were included if they were treated for at least 12 weeks. Of 359 patients, 320 patients met the inclusion criteria. The overall mortality rate was 9.7\% [31/320; 95\% confidence interval (CI): 6.0$13 \%]$. The median survival for the non-HAART and HAART groups was 31.5 and 55.9 months, respectively (log rank $=22.11, p<0.0001)$. In the multivariate analysis, the statistically significant variables were HAART and the weightfor-age Z score <-2, with HAART constituting a protective factor [relative risk (RR): 0.13; CI 95\%: 0.05-0.33] and malnutrition constituting a risk factor (RR: 3.44; CI 95\%: 1.60-7.40) for death. The incidence of death was 5.1/100 person-years in the non-HAART group and 0.8/100 person-years in the HAART group $(p<0.0001)$.

Key words: HIV - children and adolescents - historic cohort - survival - HAART

By the end of 2009, an estimated 33.3 [95\% confidence interval (CI): $31.4-35.3]$ million people were living with human immunodeficiency virus (HIV) worldwide and 2.5 (95\% CI: 1.7-3.4) million of these were children. Despite improvements in care and access to antiretroviral (ARV) treatment in many regions of the world, 1.8 (95\% CI: 1.6-2.1) million people with immune deficiency syndrome (AIDS) died in 2009 and 260,000 (95\% CI: $150,000-360,000)$ of these died before reaching the age of 15 (UNAIDS 2010). From the beginning of the epidemic in 1981 up until June 2010, 19,203 cases of AIDS infection in children younger than 12 years old have been reported in Brazil (MS 2010).

In several studies that examined the natural history of perinatal HIV/AIDS infection in children, AIDS-defining conditions were strongly associated with death (Scott et al. 1989, Blanche et al. 1990, Tovo et al. 1992, ECS 1994, IRHIC 1994, Kline et al. 1995). HIV mortality in children has decreased by $80-90 \%$ since the introduction of protease inhibitor (PI)-containing ARV regimens and opportunistic and other related infections have significantly decreased in HIV-infected children in the highly active antiretroviral therapy (HAART) era (de Martino et al. 2000, Gortmaker et al. 2001, Gibb et al. 2003, Selik \&

+ Corresponding author: jpinto@medicina.ufmg.br Received 19 September 2011

Accepted 21 March 2012
Lindegren 2003, McConnel et al. 2005, Gona et al. 2006, Judd et al. 2007, Candiani et al. 2007, USWGARV 2011). In the Children with HIV Early Antiretroviral Therapy trial on ARV treatment strategies, early HIV diagnosis and early ARV therapy reduced early infant mortality by $76 \%$ and HIV progression by $75 \%$ (Violari et al. 2008).

HAART use in the treatment of HIV-infected patients, in addition to prophylaxis for opportunistic infections, has reduced AIDS-related deaths in several countries, including Brazil (Matida et al. 2002, Marins et al. 2003). However, few studies in our country describe survival improvements in HIV-infected paediatric patients using HAART (Matida et al. 2002, Marins et al. 2003, Candiani et al. 2007). This cohort study assessed the impact of HAART, defined as a regimen containing three or more ARV drugs, on the survival and death rates of HIV-infected children and adolescents in Belo Horizonte, Brazil.

\section{PATIENTS, MATERIALS AND METHODS}

Population - This study was conducted from March 1989-June 2006 at the Training and Reference Center in Infectious Diseases (CTR-DIP) in Belo Horizonte. All patients aged zero-19 years old who had been vertically infected with HIV/AIDS according to the criteria established by the Brazilian Ministry of Health (MS 2004, 2009) had been admitted between March 1989-December 2004, had made at least two visits and had been monitored until June 2006 were included in the study. Patients must have been taking a HAART for any 12 -week period.

The children and adolescents admitted in this program underwent periodic clinical and laboratory evaluations conducted by paediatricians trained in HIV care. 
Clinic visits typically occurred monthly during the first six months of life and either every three months thereafter or at shorter intervals if clinically required. A laboratory assessment consisting of a complete blood count and a CD4 and viral load analysis was performed every three months.

ART became available after 1991, HAART was available after 1996 and laboratory data for CD4 and viral load were consistently available after 1997.

Data collection - Medical records and laboratory data were collected using standardised forms that included demographic information, HIV mode of acquisition, anthropometric measurements, clinical outcomes, CD4 lymphocyte count and plasma viral load quantification. Information about anthropometric measurements, clinical outcomes and ARV use was updated every six months. Information on hospital admission and death was obtained from medical records and was supplemented by consulting hospital records. Data from death certificates were verified through the State Health Department information system. To minimise the bias of a retrospective study, medical records were reviewed simultaneously by three specialists in infectious paediatric diseases who used standardised criteria to define the participants' clinical outcomes (CDC 1994, MS 2004, 2009). All patients were classified according to the 1994 Centers for Disease Control and Prevention (CDC) criteria (CDC 1994).

Definitions - Follow-up status was categorised as (i) in follow-up, with at least one visit in 2006, (ii) lost to follow-up, without a consultation in 2006, (iii) confirmed death or (iv) patient transfer, when confirmation of clinic transfer was available.

For children and adolescents lost to follow-up or transferred during the observation period, survival was assessed at the last clinic visit. Patients who were still alive at the end of the observation period were assessed on their last clinic visit.

Patients were divided into two groups: (i) HAART group, an ARV regimen of at least three drugs for a minimum of 12 weeks consisting of two nucleoside analogue reverse transcriptase inhibitors (NRTIs) combined with a PI or a non-nucleoside reverse transcriptase inhibitor or three NRTIs and (II) non-HAART group, patients not using antiretroviral or using antiretroviral regimes with fewer than three drugs. The research team did not interfere in the selection of the patient's ARV regimen.

Study population - During the period between March 1989-December 2004, 359 HIV-infected children and adolescents were admitted. Thirty-nine of these patients were excluded because they were not vertically HIV infected (29 patients) or had received HAART for less than 12 weeks leading up to the last consultation or death (10 patients). The remaining 320 cases were included in the analysis.

Statistical analysis - Statistical analyses were performed using SPSS version 18.0 (SPSS Inc, Chicago, IL, USA) and Epi Info version 6.04 (CDC, Atlanta, GA, USA). The anthropometric analysis was performed with the Epinut of Epi Info version 6.04 and weight/age, height/age and weight $/$ height $Z$ scores $=-2$ were considered for analysis.
The demographic, immunological and virological characteristics of the HAART and non-HAART groups were assessed using the chi-squared test $\left(\chi^{2}\right)$ and Student's $t$ test. The level of statistical significance was defined as a $\mathrm{p}$ value less than 0.05 .

In the univariate analysis, the survival curves were obtained using the Kaplan-Meier method. Log rank tests were performed to test the differences between the curves, with death as the endpoint and gender (male/ female), age range (younger than 1 year old/between 1-6 years old/older than 6 years old), weight-age $Z$ score $(\leq-2 />-2)$, height-age $Z$ score $(\leq-2 />-2)$, weight-height $\mathrm{Z}$ score $(\leq-2 />-2)$, HAART (HAART/non-HAART groups), viral load value $\log _{10}(\geq 5$ and $<5$ ) and per cent CD4 $(\leq 15 \%$ and $>15 \%)$ as the explicative variables.

In the multivariate analysis, a Cox proportional hazards model was used to calculate the predictive value of HAART on the risk of death. Variables with $p<0.25$ in the univariate analysis were also used in the model's construction to assess each variable's contribution to the endpoint occurrence (death). The limit for statistical significance was defined as $\mathrm{p}<0.05$ and $95 \%$ CIs were calculated for the relative risk (RR).

The incidence rates of death per 100 person/years were calculated for the HAART and non-HAART groups. The incidence rates in people-years were obtained by dividing the number of events observed by the sum of the years each subject contributed to the study, as assessed at the time of the event (death), loss to follow-up or the end of the follow-up period.

The information obtained was confidential and the study was approved by the Ethical Committee of Federal University of Minas Gerais.

\section{RESULTS}

The study included 320 HIV-infected children and adolescents admitted to the CTR-DIP from March 1989December 2004 and followed until June 2006. The median age at admission was 20.9 (interquartile range: 8.7-46.3) months; $172(53.8 \%)$ patients were female. The median follow-up was 49.4 months (27.7-71.4) with a median of 27 visits per patient (15-42). The median age at the beginning of HAART was 40.8 months (17.078.8) and the median follow-up time for patients using HAART was 56 months (40.3-71.0); 112 patients (35\%) were the family index case.

Over the 18 years of the study, the overall mortality rate was $9.7 \%(31 / 320 ; 95 \%$ CI: $6-13 \%)$; there were $35(10.9 \%)$ losses to follow-up and $21(6.6 \%)$ transfers to other health services. The remaining 233 (72.8\%) patients received follow-up until June 2006. Of the 31 patients who died during the study, $20(64.5 \%)$ were female and $25(80.6 \%)$ had a severe (clinical category C) HIVassociated disease (CDC 1994) at the time of death. The median age at death was 7.7 (5.1-10.7) years. Causes of death could be ascertained in 24 of $31(77.4 \%)$ patients. The most common cause of death was pneumonia (7/31: $22.6 \%$ ), followed by sepsis (5/31: 16.1\%), Pneumocystis jiroveci pneumonia (4/31: $12.9 \%)$, oesophageal candidiasis (2/31: 6.5\%), extra-pulmonary cryptococcosis (2/31: $6.5 \%$ ), cerebral toxoplasmosis (1/31: $3.2 \%$ ), malignancy 
(1/31: $3.2 \%)$, disseminated varicella (1/31: $3.2 \%)$ and wasting syndrome (1/31: $3.2 \%)$.

Table I shows the demographic, immunological and virological characteristics in the HAART and nonHAART groups at the Paediatric AIDS Outpatient Clinic at CTR-DIP from 1989-2006.

The HAART and non-HAART groups did not differ demographically by gender or age upon admission. Follow-up times and median survival times were significantly higher in the HAART group than in the nonHAART group. Clinically, more patients died in the non-HAART group than in the HAART group.

Patients in the HAART group presented the lowest values for weight/age and height-for-age $\mathrm{Z}$ scores upon admission. The same trend was noticed in the laboratory parameters, with patients in the HAART group presenting lower CD4 counts and higher viral loads upon admission.

Table II shows the univariate analysis of the risk factors for death in the 320 patients assessed in the cohort.

Gender and age did not present a statistically significant difference in relation to death. Because $p$ value for age range was below 0.25 , this variable was initially considered in the multivariate analysis.

Anthropometric variables weight-for-age and weightfor-height $Z$ scores were statistically significant in the univariate analysis. To avoid collinearity, only the weightfor-age $\mathrm{Z}$ score was included in the multivariate analysis.

Laboratory data for CD4 and viral loads became consistently available only after July 1997, when 14 deaths
(45.2\% of the total) had already occurred. Although the $\mathrm{CD} 4 \%$ was statistically significant in the univariate analysis, it was not included in the multivariate analysis because data were available only for $71 \%$ of the patients. The same result occurred with the viral load results, which was only available in $41.9 \%$ of the patients.

Thus, the variables used for constructing the Cox proportional hazards model in the multivariate analysis were age range, weight-for-age $\mathrm{Z}$ score $<=-2$ and HAART.

Fig. 1 shows the survival curve of patients with and without HAART. Survival was significantly higher in the HAART group than in the non-HAART group.

In Fig. 2, the survival curve of the patients according to weight-for-age $\mathrm{Z}$ score upon admission indicates that the patients with a $Z$ score weight-age below -2 had more adverse survival outcomes than those patients with a $\mathrm{Z}$ score above -2 .

Among the explanatory variables used in the construction of the Cox model for the multivariate analysis, HAART use and weight-for-age $Z$ score $<-2$ remained statistically significant $(p<0.05)$. The relationship between HAART and mortality was similar when stratified by the presence or absence of low WAZ upon baseline/admission $(\mathrm{p}<0.05)$. HAART was considered a protective factor and malnutrition was a risk factor for death. The RR of 0.13 for the use of HAART meant a 7.7-fold increase in protection for those patients treated with HAART.

TABLE I

Demographic, immunological and virological characteristics in highly active antiretroviral therapy (HAART) and non-HAART groups at the Paediatric AIDS Outpatient Clinic at Training and Reference Center in Infectious Diseases from 1989-2006

\begin{tabular}{|c|c|c|c|}
\hline Characteristics & $\begin{array}{l}\text { HAART group } \\
\qquad(\mathrm{n}=187)\end{array}$ & $\begin{array}{l}\text { Non-HAART group } \\
\quad(\mathrm{n}=133)\end{array}$ & $\mathrm{p}$ \\
\hline \multicolumn{4}{|l|}{$\operatorname{Sex}[n(\%)]$} \\
\hline Male & $91(48.7)$ & $57(42.9 \%)$ & 0.309 \\
\hline Female & $96(51.3)$ & $76(57.1 \%)$ & - \\
\hline Age at admission (months) [median (IQR)] & $19.7(8.1-46.3)$ & $23.9(10.4-46.5)$ & 0.155 \\
\hline Follow-up time (months) [median (IQR)] & $72.5(55.6-96.3)$ & $32.4(7.7-76.0)$ & $<0.001$ \\
\hline Median survival time (months) & 55.9 & 31.5 & 0.014 \\
\hline \multicolumn{4}{|l|}{ Clinical evolution $[\mathrm{n}(\%)]$} \\
\hline In follow-up & $164(87.7)$ & $69(51.9)$ & $<0.001$ \\
\hline Death & $7(3.7)$ & $24(18)$ & - \\
\hline Loss to follow-up & $6(3.2)$ & $29(21.8)$ & - \\
\hline Transfer & $10(5.4)$ & $11(8.3)$ & - \\
\hline Z-score weight-for-age at admission [median (IQR)] & $-1.70(-2.6--0.64)$ & $-1.25(-2.6--0.07)$ & 0.040 \\
\hline Z-score height-for-age at admission [median (IQR)] & $-1.79(-2.72--0.96)$ & $-1.35(-2.28--0.23)$ & 0.011 \\
\hline Z-score weight-for-height at admission [median (IQR)] & $-0.55(-1.27--0.19)$ & $-0.40(-1.25--0.42)$ & 0.368 \\
\hline $\begin{array}{l}\text { CD4 (\%) at admission [median (IQR)] } \\
\text { n = } 227(71 \%) ; \text { unavailable data: } 93(29 \%)\end{array}$ & $18.7(13.7-25.2)$ & $21.0(14.9-30.4)$ & 0.021 \\
\hline $\begin{array}{l}\log _{10} \text { viral load at admission [median (IQR)] } \\
\mathrm{n}=134(41.9 \%) ; \text { unavailable data: } 186(58.1 \%)\end{array}$ & $5.13(4.47-5.61)$ & $4.74(3.88-5.39)$ & 0.001 \\
\hline
\end{tabular}

IQR: interquartile range. 
The interaction between the two explanatory variables remaining in the final model (HAART and weightfor-age Z-score $\leq-2$ ) was assessed, resulting in a nonsignificant $p$ value $(p=0.49)$, indicating that the two variables were independent.

The incidence of death was 5.1/100 and 0.8/100 person-years in the non-HAART group and HAART group, respectively $(\mathrm{p}<0.001)$.

\section{DISCUSSION}

We reported the follow-up of 320 vertically HIV-infected children over a period of 18 years in a HIV-referral centre in Minas Gerais, Brazil. During the study period, many ARV drugs became available for paediatric use and our work documents the impact of ARV treatment on the infected children's survival.
The study cohort represents the epidemiologic behaviour of HIV-infected paediatric patients in our country. Although our study assessed only patients with vertical HIV transmission, the vertical route represented $80.6 \%$ of the cases in our service, which is similar to the $85 \%$ cases reported to the MS in Brazil in 2008 (MS 2010). Within the 18 -year follow-up period, only $10.9 \%$ of our subjects were lost to follow-up and the child mortality rate was $9.7 \%$. The overall loss to follow-up was $10.3 \%$. However, subjects in the non-HAART group presented higher loss to follow-up than those subjects in the HAART group. The difference in loss to follow-up rates could be attributed to the intrinsic nature of our study design. In this historic cohort study, subjects in the non-HAART group were admitted in the early years when the clinic procedures for follow-up were not fully implemented.

TABLE II

Univariate analysis of risk factors for death in 320 human immunodeficiency virus-infected children and adolescents in Belo Horizonte, Brazil from 1989-2006

\begin{tabular}{|c|c|c|c|c|}
\hline Variables & $\begin{array}{l}\text { Death } \\
(\mathrm{n}=31)\end{array}$ & $\begin{array}{l}\text { Non-death } \\
(\mathrm{n}=289)\end{array}$ & Log rank & $\mathrm{p}$ \\
\hline \multicolumn{5}{|l|}{$\operatorname{Sex}[\mathrm{n}(\%)]$} \\
\hline Male & $11(35.5)$ & $137(47.4)$ & 1.347 & 0.2460 \\
\hline Female & $20(64.5)$ & $152(52.6)$ & - & - \\
\hline \multicolumn{5}{|c|}{ Age range at admission $[\mathrm{n}(\%)]$} \\
\hline$<1$ year & $9(29)$ & $93(32.2)$ & 4.284 & 0.117 \\
\hline $1-6$ years & $14(45.2)$ & $160(55.4)$ & - & - \\
\hline$>6$ years & $8(25.8)$ & $36(12.4)$ & - & - \\
\hline \multicolumn{5}{|c|}{$\mathrm{Z}$ score weight-for-age $\leq-2$ at admission $[\mathrm{n}(\%)]$} \\
\hline Yes & $17(54.9)$ & $96(33.2)$ & 5.480 & 0.019 \\
\hline No & $13(41.9)$ & $185(64)$ & - & - \\
\hline Unavailable data $^{a}$ & $1(3.2)$ & $8(2.8)$ & - & - \\
\hline \multicolumn{5}{|c|}{ Z-score height-for-age $\leq-2$ at admission $[\mathrm{n}(\%)]$} \\
\hline Yes & $15(48.4)$ & $102(35.3)$ & 3.644 & 0.056 \\
\hline No & $12(38.7)$ & $179(61.9)$ & - & - \\
\hline Unavailable data $^{a}$ & $4(12.9)$ & $8(2.8)$ & - & - \\
\hline \multicolumn{5}{|c|}{ Z-score weight-for-height $\leq-2$ at admission $[\mathrm{n}(\%)]$} \\
\hline Yes & $8(25.8)$ & $25(8.7)$ & 11.226 & 0.001 \\
\hline No & $18(58.1)$ & $235(81.3)$ & - & - \\
\hline Unavailable data $^{a}$ & $5(16.1)$ & $29(10)$ & - & - \\
\hline \multicolumn{5}{|c|}{ Highly active antiretroviral therapy [n (\%)] } \\
\hline No & $24(77.4)$ & $109(37.7)$ & 22.111 & $<0.001$ \\
\hline Yes & $7(22.6)$ & $180(62.3)$ & - & - \\
\hline \multicolumn{5}{|c|}{ CD4 percent $[\mathrm{n}(\%)]$} \\
\hline \multicolumn{5}{|c|}{ [last date available near the event of the study (last visit or death)] } \\
\hline$\leq 15 \%$ & $15(48.4)$ & $69(23.9)$ & 15.862 & $<0.001$ \\
\hline$>15 \%$ & $7(22.6)$ & $192(66.4)$ & - & - \\
\hline Unavailable data $^{a}$ & $9(29)$ & $28(9.7)$ & - & - \\
\hline \multicolumn{5}{|c|}{$\begin{array}{l}\text { Viral load } \log _{10}[\mathrm{n}(\%)] \\
\text { [last date available near the event of the study (last visit or death)] }\end{array}$} \\
\hline$\geq 5$ & $9(29)$ & $132(45.7)$ & 2.488 & 0.115 \\
\hline$<5$ & 4 (12.9) & $136(47.1)$ & - & - \\
\hline Unavailable data $^{a}$ & $18(58.1)$ & $21(7.2)$ & - & - \\
\hline
\end{tabular}

$a$ : excluded from statistical analysis. 
Although ARV treatment has been available in Brazil since 1991, it was restricted to mono or dual therapy with NRTIs. Starting in 1996, a wider range of ARV drugs, including PIs, became available and the universal, freeof-charge national ARV program was strengthened. The impact of this strategy has been measured in a national study carried out among HIV-infected adults. Patients diagnosed in 1996 had an average survival rate three times greater than those diagnosed in 1995 (Marins et al. 2003).

Although not significant $(\mathrm{p}=0.072)$, subjects in the HAART group tended to be admitted at younger ages at the clinic, possibly because the HAART group had patients with more severe symptoms who typically sought care earlier. Patients in this group also presented as more severely malnourished, with lower CD4 counts and higher viral loads at admission. Scott et al. (1989) observed that in patients with milder manifestations of the disease, recognising the infection during the first year of life is less likely, whereas children with a more advanced version of the disease are typically identified earlier (Scott et al. 1989).

Most patients who died in our study presented with clinical category C advanced HIV disease (CDC 1994) at the time of death. Although many of these children were exposed to ARVs during the clinical follow-up period, treatment tended to start late. In a European collaborative study (ECS 2006), HIV-infected children who began HAART at an advanced (category C) stage of the disease (CDC 1994) had an 84\% lower chance of immunological recovery ( $20 \%$ increase in CD4) compared to those children who began HAART at the onset of mild/moderate symptoms (categories N, A and B) (CDC 1994).

This study presents limitations inherent to the retrospective method. Data on clinical exams, laboratory exams and disease progression were obtained from medical records. Some information may not have been properly recorded, despite routine use of standardised forms. To minimise the flaws of the retrospective study design, all clinical records were reviewed and discussed by three paediatric HIV specialists using consistent criteria for defining patients' clinical conditions.

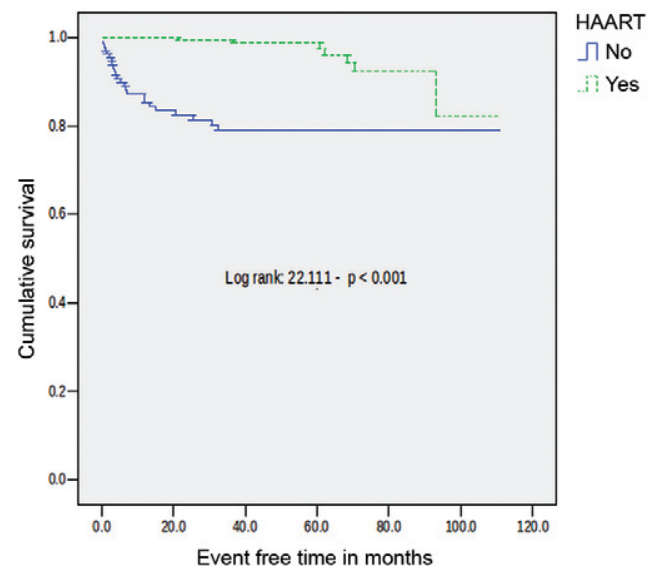

Fig. 1: survival curve of patients with and without use of highly active antiretroviral therapy (HAART).
More powerful ARV regimens and the increased use of prophylaxis for opportunistic infections have increased the number of HIV-infected children who currently survive until adolescence (Frederick et al. 2000, Selik \& Lindegren 2003). This improvement in patient management has led to changes in the disease's clinical progression, resulting in lower morbidity and mortality (MS 2009, USWGARV 2011).

This study observed a significant improvement in patients' survival times and a reduction in the number of deaths among patients using HAART. In another Brazilian study, a reduction of $87.8 \%$ in the death rate of vertically HIV-infected children was observed from 19942002 (Matida et al. 2005). Several studies in Europe and the United States have also demonstrated HAART's effectiveness in reducing child mortality (Essajee et al. 1999, Teglas et al. 2000, Gortmaker et al. 2001, van Rossum et al. 2001, 2002, Goethebuer et al. 2009, Kapogiannis et al. 2011, Peacock-Villada et al. 2011). In a Spanish cohort, HAART decreased the progression of HIV infection, with an estimated reduction of $43 \%$ of the risk of developing AIDS after five years (Granados et al. 2003).

In a study by Mocroft et al. (1998), the death rate in adults was 65.4 per 100 person-years in follow-up in patients without ARV treatment, 7.5 per 100 person-years in follow-up in patients using dual therapy and 3.4 per 100 person-years in follow-up in patients who received triple therapy. In our cohort, a reduction in the death rate from 5.1/100 person-years in the non-HAART group to $0.8 / 100$ person-years $(p<0.001)$ in the HAART group was observed.

In the univariate analysis by the Kaplan-Meier method, we observed more adverse clinical outcomes in patients who were malnourished upon admission. According to the literature, growth impairment in HIV-infected children is a well-known indicator that often precedes a decrease in the $\mathrm{CD}^{+}$cell count (Brettler et al. 1990). The improvement in growth parameters can be applied as an efficacy measure of HAART, with viral replication control exercising a positive effect on both height and weight (Verweel et al. 2002).

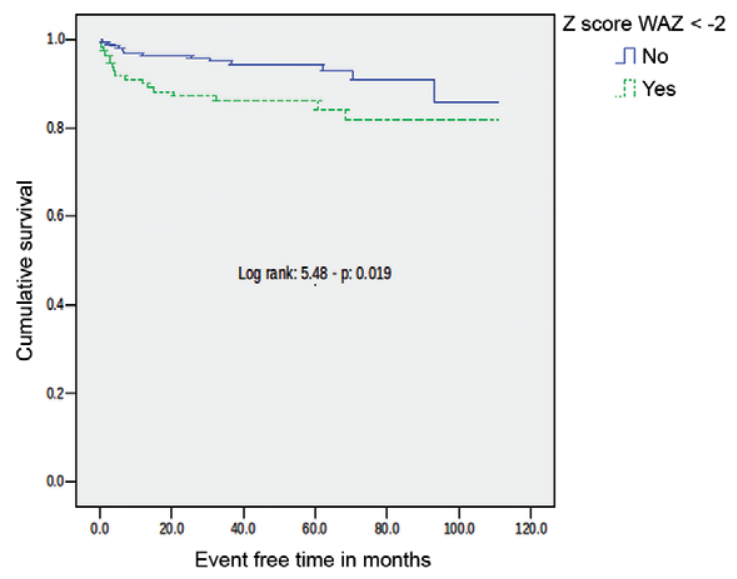

Fig. 2: survival curve of the patients according to weight-for-age $Z$ score (WAZ) at admission. 
Our patients with a $\mathrm{CD} 4^{+}$cell count below $15 \%$ and a viral load above $5 \log _{10}$ had the most adverse clinical progression, with the greatest risk of death. These findings are consistent with Mofenson et al. (1997), who showed that levels of plasmatic viremia above 100,000 copies/ $\mathrm{mL}(5 \mathrm{log})$ and $\mathrm{T} \mathrm{CD} 4^{+}$lymphocyte counts below $15 \%$ in children over 30 months old are independent predictors of increased risks for clinical (category C) disease progression (CDC 1994) or death.

In the final multivariate analysis model, a lower risk of death in the HAART group and the greatest risks among patients with a $\mathrm{Z}$ score weight-for-age below -2 remained significant. The data presented in this paper support HAART's effectiveness in reducing mortality for patients who are malnourished upon admission.

One of our work's strengths lies in how long we were able to conduct follow-up for children and adolescents in the same clinic. Our observation started before HAART was available or broadly used in Brazilian children.

HAART significantly changed the prognosis of an HIV infection in countries where therapy was successfully implemented, including Brazil. Although HIV is a relatively recent epidemic, much has already been achieved. An improved quality of life and an increased life span for HIV-infected children has been observed since therapeutic strategies were developed. Infected infants and children now survive until adolescence or beyond into adulthood and the current challenge in care is how to handle a chronic disease with acute flares.

This study shows that it is possible to use HAART to treat HIV-infected children and adolescents in resourcelimited countries and that this treatment is as effective as it is in developed countries. HAART can be administered safely and effectively to children and adolescents in countries with limited resources (Rouet et al. 2006) with results that are comparable to the results of clinical trials with ARVs in children in developed countries (Fassionou et al. 2004, Kline et al. 2004).

\section{REFERENCES}

Blanche S, Tardieu M, Duliège AM, Rouzioux C, Le Deist F, Fukunaga K, Caniglia M, Jacomet C, Messiah A, Griscelli C 1990. Longitudinal study of 94 symptomatic infants with perinatally acquired human immunodeficiency virus infection: evidence for a bimodal expression of clinical and biological symptoms. Am J Dis Child 144: 1210-1215.

Brettler DB, Forsberg A, Bolivar E, Brewster F, Sullivan J 1990. Growth failure as a prognostic indicator for progression to acquired immunodeficiency syndrome in children with hemophilia. J Pediatr 117: 584-588.

Candiani TMS, Pinto JA, Cardoso CAA, Carvalho IR, Dias ACM, Carneiro M, Goulart EA 2007. Impact of highly active antiretroviral therapy (HAART) on the incidence of opportunistic infections, hospitalizations and mortality among children and adolescents living with HIV/AIDS in Belo Horizonte, Minas Gerais State, Brazil. Cad Saude Publica 23 (Suppl. 3): S414-S423.

CDC - Centers for Disease Control and Prevention 1994. 1994 revised classification system for human immunodeficiency virus (HIV) infection in children less than 13 years of age. MMWR 43: 1-10.

De Martino M, Tovo PA, Balducci M, Galli L, Gabiano C, Rezza G, Pezzotti P, Italian Register for HIV Infection in children and the
Italian National AIDS Register 2000. Reduction in mortality with availability of antiretroviral therapy for children with perinatal HIV-1 infection. JAMA 284: 190-197.

ECS - European Collaborative Study 1994. Natural history of vertically acquired human immunodeficiency virus-1 infection. Pediatrics 94: 815-819.

ECS - European Collaborative Study 2006. CD4 cell response to antiretroviral therapy in children with vertically acquired HIV infection: is it associated with age at initiation? J Infect Dis 193: 954-962.

Essajee S, Kim M, Gonzalez C, Rigaud M, Kaul A, Chandwani S, Hoover W, Lawrence R, Spiegel H, Pollack H, Krasinski K, Borkowsky W 1999. Immunologic and virologic responses to HAART in severely immunocompromised HIV-1 infected children. AIDS 13: 2323-2332.

Fassinou P, Elenga N, Rouet F, Laguide R, Kouakoussui KA, Timite M, Blanche S, Msellati P 2004. Highly active antiretroviral therapy among HIV-1-infected children in Abidjan, Côte d'Ivoire. AIDS 18: 1905-1913.

Frederick T, Thomas P, Mascola L, Hsu Ho-Wen, Rakusan T, Mapson C, Weedon J, Bertolli J 2000. Human immunodeficiency virusinfected adolescents: a descriptive study of older children in New York city, Los Angeles County, Massachusetts and Washington, DC. Pediatr Infect Dis J 19: 551-555.

Gibb DM, Duong T, Tookey, Tudor-Williams G, Novelli V, Bultler K, Riordan A, Farrelly L, Masters J, Peckham CS, Dunn DT, National Study of HIV in Pregnancy and Childhood Collaborative HIV Paediatric Study 2003. Decline in mortality, AIDS, and hospital admissions in perinatally HIV-1 infected children in the United Kingdom and Ireland. BMJ 327: 1019-1023.

Goethebuer T, Haelterman E, Le Chenadec J, Dollfus C, Gibb D, Judd A, Green H, Galli L, Ramos JT, Giaquinto C, Warszawski J, Levy J, European Infant Collaboration group 2009. Effect of early antiretroviral therapy on the risk of AIDS/death in HIV-infected infants. AIDS 23: 597-604.

Gona P, van Dyke R, Williams PL, Dankner WM, Chernof ML, Nachman SA, Seage GR 2006. Incidence of opportunistic and others infections in HIV-infected children in the HAART era. JAMA 296: 292-300.

Gortmaker SL, Hughes M, Cervia J, Brady M, Johnson GM, Seage GR, Song LY, Dankner WM, Oleske JM, for The Pediatric AIDS Clinical Trial Group 219 team 2001. Effect of combination therapy including protease inhibitors on mortality among children and adolescents infected with HIV-1. N Engl J Med 345: 1522-1528.

Granados JMS, Amador JTR, Miguel SF, Tomé MIG, Conejo PR, Vivas PF 2003. Impact of highly antiretroviral therapy on the morbidity and mortality in Spanish human immunodeficiency vírusinfected children. Pediatr Infect Dis J 22: 863-867.

IRHIC - Italian Register for HIV Infection in Children 1994. Features of children perinatally infected with HIV-1 surviving longer than 5 years. Lancet 343: 191-195.

Judd A, Doerholt K, Tookey PA, Sharland M, Riordan A, Menson E, Novelli V, Lyall EG, Masters J, Tudor-Williams G, Duong T, Gibb DM, Collaborative HIV Paediatric Study (CHIPS), National Study of HIV in Pregnancy and Childhood (NSHPC) 2007. Morbidity, mortality and response to treatment by children in the United Kingdom and Ireland with perinatally acquired HIV infection during 1996-2006: planning for teenage and adult care. Clin Infect Dis 45: 918-924.

Kapogiannis BG, Soe MM, Nesheim SR, Abrams EJ, Carter RJ, Farley J, Palumbo P, Koenig LJ, Bulterys M 2011. Mortality trends in the US Perinatal AIDS Collaborative Transmission Study (19862004). Clin Infect Dis 53: 1024-1034. 
Kline MW, Matusa RF, Copaciu L, Calles NR, Kline NE, Schwarzwald HL 2004. Comprehensive pediatric human immunodeficiency virus care and treatment in Constanta, Romania. Implementation of a Program of highly active antiretroviral therapy in a resource-poor setting. Pediatr Infect Dis J 23: 695-700.

Kline MW, Paul ME, Bohannon B, Kozinetz CA, Shearer WT 1995. Characteristics of children surviving to 5 years of age or older with vertically acquired HIV infection. Pediatr AIDS HIV Infect Fetus Adolesc 6: 350-353.

Marins JRP, Jamal LF, Chen SY, Barros MB, Hudes ES, Barbosa AA, Chequer P, Teixeira PR, Hearst N 2003. Dramatic improvement in survival among adult Brazilian AIDS patients. AIDS 17: $1675-1682$

Matida LH, Marcopito LF, Grupo Brasileiro de Estudo da Sobrevida em Crianças com AIDS 2002. Aumento do tempo de sobrevida das crianças com AIDS - Brasil. Coordenação Nacional de DST-AIDS. Boletim Epidemiológico 4. [accessed on September 13, 2011]. Available from: aids.gov.br/data/documents/storedDocuments/\%7BB8EF5DAF-23AE-4891-AD36 $1903553 \mathrm{~A} 3174 \% 7 \mathrm{D} / \% 7 \mathrm{~B} 3 \mathrm{C} 849 \mathrm{~B} 6 \mathrm{E}-\mathrm{AF} 5 \mathrm{E}-48 \mathrm{DE}-9 \mathrm{DC} 1$ 2AC2DBED6873\%7D/bol marco 2002.pdf.

Matida LH, Silva MH, Tayra A, Succi RCM, Gianna MC, Gonçalves A, de Carvalho HB, Hearst N 2005. Prevention of mother-tochild transmission of HIV in São Paulo state, Brazil: an update. AIDS 19 (Suppl. 4): S37-S41.

McConnel MS, Byers RH, Frederick T, Peters VB, Dominguez KL, Sukalac T, Greenberg AE, Hsu HW, Rakusan TA, Ortiz IR, Melville SK, Fowler MG, Pediatric Spectrum of HIV Disease Consortium 2005. Trends in antiretroviral therapy use and survival rates for a large cohort of HIV-infected children and adolescents in the United States, 1989-2001. J Acquired Immune Defic Syndr 38: 488-494.

Mocroft MA, Vella S, Benfield TL, Chiesi A, Miller V, Gargalianos P, d'Arminio Monforte A, Yust I, Bruun JN, Phillips AN, Lundgren JD 1998. Changing patterns of mortality accross Europe in patients infected with HIV-1. Lancet 352: 1725-1730.

Mofenson LM, Korelitz J, Meyer WA, Bethel J, Rich K, Pahwa S, Moye J Jr, Nugent R, Read J 1997. The relationship between serum human immunodeficiency virus type 1 (HIV-1) RNA level, CD4 lymphocyte percent and long-term mortality risk in HIV-1infected children. Journal Infect Dis 175: 1029-1038.

MS - Ministério da Saúde 2004. Secretaria de Vigilância em Saúde. Programa Nacional de DST e AIDS. Critérios de definição de casos de AIDS em adultos e crianças. [accessed on September 13, 2011]. Available from: saude.rj.gov.br/Docs/Dstaids/criterios.pdf.

MS - Ministério da Saúde 2009. Secretaria de Vigilância em Saúde. Programa Nacional de DST e AIDS. Guia de tratamento clínico da infecção pelo HIV em crianças. Programa Nacional de DST e AIDS. [accessed on September 13, 2011]. Available from: aids. gov.br/sites/default/files/consenso pediatrico.pdf.

MS - Ministério da Saúde 2010. Programa Nacional de DST e AIDS. Boletim Epidemiológico 1. [accessed on September 13, 2011]. Available from aids.gov.br/sites/default/files/anexos/ publicacao/2010/45974/boletim_2010_pdf_14544.pdf.
Peacock-Villada E, Richardson BA, John-Stewart GC 2011. PostHAART outcomes in pediatric populations: comparison of resource-limited and developed countries. Pediatrics 127: 423-441.

Rouet F, Fassinou P, Inwoley A, Anaky MF, Kouakoussui A, Rouzioux C, Blanche S, Msellati P 2006. Long-term survival and immunovirological response of African HIV-1-infected children to highly active antiretroviral therapy regimens. AIDS 20: 2315-2319.

Scott GB, Hutto C, Makuck RW, Mastrucci MT, O'Connor T, Mitcheli CD, Trapido EJ, Parks WP 1989. Survival in children with perinatally acquired human immunodeficiency virus type 1 infection. N Engl J Med 321: 1971-1976.

Selik RM, Lindegren ML 2003. Changes in deaths reported with human immunodeficiency virus infection among United States children less than 13 years old, 1987 through 1999. Pediatr Infect Dis J 22: 635-641.

Teglas J, Mayaux M, Blanche S 2000. Antiretroviral therapy and mortality among children with perinatal HIV infection. JAMA 284: 2871-2872.

Tovo P, Gabiano C, Palomba E, De Martino M, Galli L, Cappello N, D'Elia R, Loy A, Plebani A, Zuccotti GV, Dallacasa P, Ferraris G 1992. Prognostic factors and survival in children with perinatal HIV-1 infection. Lancet 339: 1249-1253.

UNAIDS - Joint United Nations Programme on HIV/AIDS (UNAIDS) and World Health Organization 2010. AIDS Epidemic Update 2010. [accessed on September 13, 2011]. Available from unaids.org/documents/20101123_GlobalReport_Chap2 em.pdf.

USWGARV - The Working Group on Antiretroviral Therapy and Medical Management of HIV-infected Children 2011. Guidelines for the Use of Antiretroviral Agents in Pediatric HIV Infection. [accessed on September 13, 2011]. Available from: AIDSinfo.nih.gov/guidelines/.

van Rossum AM, Geelen S, Hartwing N, Wolfs TFW, Weemaes CMR, Scherpbier HJ, van Lochem EG, Hop WC, Schutten M, Osterhaus AD, Burger DM, de Groot R 2002. Results of 2 years of treatment with protease-inhibitor-containing antiretroviral therapy in Dutch children infected with human immunodeficiency virus type 1. Clin Infect Dis 34: 1008-1016.

van Rossum AM, Scherpbier HJ, van Lochem EG, Pakker NG, Slieker WAT, Wolthers KC, Roos MT, Kuijpers JH, Hooijkaas H, Hartwig NG, Geelen SP, Wolfs TF, Lange JM, Miedema F, de Groot R, Dutch Study Group for Children with HIV Infections 2001. Therapeutic immune reconstitution in HIV-1 infected children is independent of their age and pre treatment immune status. AIDS 15: 2267-2275.

Verweel G, van Rossum AM, Hartwing NG, Wolfs TF, Scherpbier HJ, de Groot R 2002. Treatment with highly active antiretroviral treatment in human immunodeficiency virus type 1-infected children is associated with a sustained effect on growth. Pediatrics 109: e25.

Violari A, Paed FC, Cotton MF, Med M, Gibb DM, Babiker AG, Steyn J, Madhi SA, Jean-Philippe P, McIntyre JA, for the CHER Study Team 2008. Early antiretroviral therapy and mortality among HIV-infected infants. N Engl J Med 359: 2233-2244. 